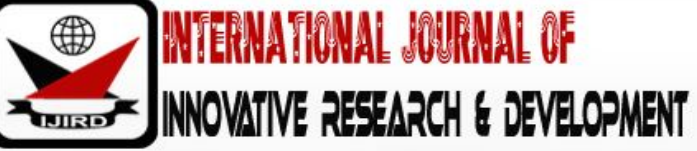

ISSN 2278 - 0211 (Online)

\section{Influence of Learners' Practical Process Skills' Competency on Their Attitude towards Biology}

\begin{tabular}{c} 
Isaac Odawa Christopher Imanda \\
Part-time Lecturer, Kisii University, Kenya \\
Dr. Ezekiel Nyambega Omwenga \\
Dr. George Morara Andima \\
Lecturer, Department of Curriculum Instruction and Media, Kisi University, Kenya \\
Lecturer, Department of Curriculum Instruction and Media, Kisii University, Kenya \\
Dr. Enock Obuba \\
Lecturer Department of Curriculum, Instruction and Media, Kisii University, Kenya \\
\hline
\end{tabular}

\begin{abstract}
Learners' attitude towards biology is a key determinant of how students learn. Attitude development is a process that is influenced by what happens in and around the learners' learning environment. This study sort to establish the influence that biology practical process skills teaching approach (BPPSTA) has on learners' attitude towards biology in Gucha south sub-county, Kisii County, Kenya. The study was guided by two objectives: To establish the influence of BPPSTA on learners' attitude towards biology lesson when taught using BPPSTA as compared to when taught via the conventional methods and, to determine whether BPPSTA affects learners' attitude towards biology practical process skills. The Solomon's four non-equivalent control group design was used. The sample size comprised of 401 form two students out of a target population of 2,946. Data was collected using biology Attitude Questionnaire for Students (BAQS). Descriptive statistics using means and standard deviations were used for group comparison while t-test was used to test the hypotheses. The study found out that learners who were taught via BPPSTA had a more positive attitude as compared to those taught via the conventional methods. Therefore, BPPSTA had a positive contribution to learners' attitude towards both biology lessons and Biology Practical Process Skills (BPPS). The study findings may provide a baseline on the formulation of in-service training for biology teachers. The study recommends that biology teachers should often use BPPSTA so as to develop positive attitude among learners towards biology.
\end{abstract}

Keywords: Biology practical process skills, Competency, Learners' attitude, teaching approach

\section{Introduction}

The term 'attitude' has received varied definitions which have been suggested in different education disciplines; including psychology and social science. Evidence exists that show an interrelationship between learners' beliefs and their attitudes. The attitudes towards science practical is described as a more purposeful manner of putting together a wide range of beliefs concerning science that gives room for one to predict the way of science. Learner attitude toward science practical, however, may be conceived as a wide variety of beliefs that are held by learners towards science practical (Ackon, 2014). Biology is one of the three natural science subjects taught in Kenyan secondary school curriculum. The learners' attitude towards biology is key in determining the output by the learner at the end of secondary level. With favourably positive attitude it would be expected that learners will perform better in biology examinations, pursue biology-related careers and therefore motivate those learners still in school to follow suit. The present study focused on six process skills which are observing, Communicating, inferring, measuring, interpreting data and experimenting.

\subsection{Observing}

This is the use of the five senses to gather information about an object or event (KIE, 2006). Almost every activity of science begins with observation about all things around, using the senses as appropriate and safe; identifying similarities and differences; noticing details and sequence; ordering observations (Amoah et al., 2018). An example is, describing a pencil as yellow. Observing is the fundamental science process skill. Alkaslassy, and O'Day (2001) opines that, we observe objects and events using all our five senses, and this is how we learn about the world around us. According to Onamu (2011), secondary school students face difficulties when drawing tables, they fail to give adequate space for recording data or observations. Onamu's (2011) findings concur with SMASSE (2007), findings; that most secondary school students under study in Thika West Sub-County exhibited low degrees of precision in observation skill. In a study by Ngakhala et al. (2017) an interesting finding was that over $80 \%$ of the form two students who took part in the study 
were rated below average. The study focused on learners' ability to practice the science process skill called, observation. This finding reflects the poor performance in this important skill at various class levels (form 1,2 and 3).

\subsection{Communicating}

This is the use of words or graphic symbols to describe an action, object or event. Example: Describing the change in height of a plant over time in writing or through a graph. As implied already, communication, the second of the basic science process skills, goes hand in hand with observation. Students have to communicate in order to share their observations with someone else, and the communication must be clear and effective if the other person is to understand clearly the information. Steiner, McNair and Butcher (2001) opine that one of the keys to communicating effectively is to use so-called referents; these are references to items that the other person is already familiar with. For example, we often describe colors using referents. We might say sky blue, safaricom green, grass green, or lemon yellow to describe particular shades of blue, green, or yellow.

\subsection{Inferring}

Making an 'educated guess' about an object or event based on previously gathered data or information. Example: Saying that the person who used a pencil made a lot of mistakes because the eraser was much reduced in size. Unlike observations, which are direct evidence gathered about an object, inferences are explanations or interpretations that are a consequence from the observations. For example, it is an observation to say an insect released a dark, sticky liquid from its mouth, and it is an inference to explain why the liquid was released; the insect released a dark, sticky liquid from its mouth because it is upset and trying to defend itself. Susanti et al. (2018) notes that when we are able to make inferences, interpretation and explaining of events around us, we have a better appreciation and understanding of the environment around us. Learners need to be able to differentiate the evidence they gather about the world as observations and the interpretations or inferences they make based on the observations (Steiner et al., 2001).

\subsection{Measuring}

Using both standard and non-standard instruments or estimates to describe the dimensions of an object or event. Example: Using a meter rule to measure the height of a seedling in centimeters. The highest level in the SPS mastery of inservice and pre-service teachers in the skill of measuring that was $95 \%$ of the total population (Susanti et al., 2018). Also found out was an increase in the mastery of measurement skill with age of students and furthermore there was no significant relationship between teacher mastery and student mastery. The study further revealed that trained teachers showed a higher mastery of the skill than the untrained teachers.

\subsection{Interpreting Data}

According to KIE (2006) science inquiry is empirical in nature. Through experiments and observations, data is gathered. This data needs to be interpreted so that meaning and sense can be related to the data. Interpretation of data involves organizing data and drawing conclusions from it. Ona (2007) adds that the value and the necessity of the skill of interpreting data need to be given greater prominence. Data interpretation is a key process in biology learning. This process makes sense from the data collected so that the data can be viewed as having meaning. Data can be numerical or in terms of words but whatever the form, its interpretation is paramount in biology instruction.

\subsection{Experimenting}

Procedural knowledge means understanding how to do something. It includes methods of inquiry, and criteria for using skills, algorithms, techniques, and methods, knowledge of subject-specific skills and algorithms, knowledge of subject-specific techniques and methods and knowledge of criteria for determining when to use appropriate procedures (Eila et al., 2016). Several biological topics require approaches promoting experimental problem-solving and processbased skills. The focus is on science investigation processes and the goal is to reach valuable learning results.

Agogo (2002) observes that, the actual learning of integrated science has to do with the learners' attitudes so as to develop interest in the learners towards learning process. The study confirms that there is correlation between attitudes that the integrated science students come with to the science class and their academic achievements in the subject. Adodo and Gbore, (2012) additionally posit that the solution to changes in the attitude of learners lies squarely in the teachers' hands. Therefore, the teaching method a teacher adopts for use during biology classroom instruction will likely determine the attitude that learners will develop towards biology. It is upon this assertion that the present study aimed at establishing whether the use of BPPSTA during instruction has any influence on learners' attitude towards biology.

The study objectives were; to establish the influence of BPPSTA on learners' attitude towards biology lesson when taught using BPPSTA as compared to when taught via the conventional methods and, to determine whether BPPSTA affects learners' attitude towards biology practical process skills.

\subsection{Research Hypotheses}

- $\mathrm{HO}_{1}$ : There is no significant difference in attitude towards biology lessons between learners taught via the BPPSTA and those taught via the conventional methods.

- $\mathrm{HO}_{2}$ : There is no significant difference in attitude towards BPPS between learners taught via the BPPSTA and those taught via the conventional methods. 


\section{Literature Review}

\subsection{Learners Attitude towards Biology}

The learners' attitude towards biology will always vary from Gore place to place and sometimes from learner to learner. However, studies have continued to show that the happenings in the learning environment greatly influence the learners' attitude. The teacher has a role to regulate and guide what happens in the biology classroom. Sadhana (2017) observes that attitudes are mental predispositions towards people, objects, and events. Learner attitude towards practical activities would be expected to influence their participation in science and hence achievement. Hussein (2015) observes that it is important for science teachers to ensure that students have positive attitude in science subjects, but studies show that the way students are taught in science classroom is not interesting to students' success.

According to Prokop et al. (2007) majority of the students under study believed in the importance of knowledge of biology in future career. However, older students displayed a significantly higher tendency for refusing biology career. Interestingly, one fifth (20\%) of the students stated that they like to watch films about nature and therefore they would like to think about making a career in biology. Ramsden (1998) cited in Suzuki (2007) observes that students need to see the study of biology as a desirable goal; they may develop positive attitude because biology is important in key careers such as nursing, pharmacy, medicine among others. Of course, powerful aspect of attitude would be student confidence on gaining good grades. He further reveals that interest in science tends to decrease with age. The work of Reid and Skryabina (2002) clarified Ramsden's (1998) findings that, with a balance in the curriculum content the varied attitude between girls and boys won't be witnessed. Suzuki (2007) observes that learners in school develop attitudes but there are ways by which the learning experiences can encourage the development of more positive attitudes towards biology content, how it is taught and the implication arising from the content being taught.

Practical work engenders not only the science process skills appropriate for scientific inquiry but also inculcates attitudes and conceptual perspectives which are necessary for skilled scientific inquiry (KIE, 2001). The inquiry approach to teaching can only be enhanced through the application of science process skills. The findings by Bevins, Bryne, Brodie, and Price (2011) and Cleaves (2005) with regards to biology per se were that the learners had a positive attitude towards biology practical, these findings disagree with those by Sharpe, (2012) who found out that, only a few students preferred biology practical work over chemistry or physics because of it being easier to do or more relevant to their lives. This controversy in research creates an avenue for further research. This therefore necessitated the present study to be conducted so as to find out whether the methodology used in the biology classroom affected the learners' attitude towards biology.

Sharpe (2012) findings reveal that secondary students' attitudes to practical work are, generally positive however comparatively of the three sciences, learners had the least attitude in biology. In addition, what also emerged was the extent to which such attitudes to practical work differed, not only across the three sciences, but also showed a statistically significant decline as students progressed through their secondary school education. In Sharpe's study the researcher assumed that the respondents were already exposed to practical sessions hence the study did not expose them to practicals, but just went in to get their attitude towards practical. This is a gap in the study which the present study had an intention to fill by first getting attitudes of learners before they learnt using BPPSTA. There after they learnt using BPPSTA and then their attitudes were sought again. This provided an avenue for the researcher to make an informed report on their attitude change after learning through BPPSTA.

Students' attitude towards science is more likely to influence achievement in science courses than achievement influencing attitude. This standpoint is supported by a study by Akinyemi (2009) who observed that improved students' attitude towards biology will enhance students' performance in the subject. Ngesu, Gunga, Wachira, and Kaluku (2014) from their study found out that the students' attitude towards biology was rated as neutral on a three-predictor scale. The study further conceives that this neutral attitude is the contributing factor to the poor performance that was witnessed by the respondents in the biology examination. Similar findings have been reported by Ogutu et al. (2015) who asserts that, attitude if positive results into good performance while if neutral or negative it culminates into poor learner performance in examinations. The Present study on the other hand sought to determine the direction the learners' attitude will take after having been learnt using BPPSTA.

Mei, Kaling, Xinyi, Sing and Khoon (2007) undertook a study on promoting science process skills and the relevance of science through science ALIVE! programme. The findings showed significant increase in students' perception of skill competency. In addition, a high percentage of students indicated that the programme had made them more aware of the relevance of science in their lives. The present study in an attempt to counter the flaws of the described studies, subjected the learners to BAQS before and after the intervention so as to relate the change in the learners' attitude.

\subsection{Science Process Skills in Teaching Biology}

Science A Process Approach (SAPA) has grouped process skills into two types; basic and integrated. According to American Association for the Advancement of Science (AAAS) the basic science process skills comprise of observing, measuring, communicating, classifying, inferring and predicting while the integrated science process skills comprised of controlling variables, defining operationally, formulating variables, interpreting data, experimenting and formulating models (Padilla, 1990; Molefe and Michele, 2014).

Many educators consider the development of SPS in learners to be a major objective of education (Aslan, 2015). These skills are important not only in terms of preparing future scientists and technologists, but also for the whole population who need scientific literacy in order to live and function in a world where science impinges on most aspects of personal, social and global life. Process-based instruction focuses upon developing students' independence in learning and 
problem solving by providing a framework into which curriculum activities can be placed (Eila et al., 2016). SPS are a lifelong learning process that forms a basis for analytical thinking, creating knowledge by principles of 'learning by doing' used for problem solving (Aslan, 2015). The modern method of teaching science does not only involve the understanding of facts, concepts, and principles (product) but it also involves the understanding of the way this knowledge is obtained such as observing, measuring, classifying, collecting data, experimenting (process) (Ona, 2007). These studies do not however clearly inform whether attitude has any influence on acquisition of the process skills. The present study therefore sought to unveil where such an influence exists.

Rambuda and Fraser (2004) maintain that basic science process skills are interdependent, implying that investigators may display and apply more than one of the skills in any single activity. They go further to explain for instance, to 'measure' the area of a habitat, the biology student may start by 'observing' the habitat, then 'measure' the dimensions and communicate the same using a symbol. Thereafter the student may 'calculate' the area and presents it. In this scenario, the student was involved in the skill of observing, measuring and communication. Akinbobola (2008) analyzed science process skills in West African senior secondary school certificate physics practical examinations in Nigeria for a period of 10 years (1998-2007). The study recommended that the examination bodies in Nigeria should include more integrated science process skills into the senior secondary school physics practical examinations so as to enable the students to develop creativity, problem solving, reflective thinking, originality and invention which are vital ingredients for science.

Molefe and Michele (2014) conducted a study on science teacher educators' views and practice regarding science process skills in South Africa. The study found out that the national education policy documents for initial teacher education lays a lot of emphasis on the competence of teachers 'in procedures, methods, principles, knowledge, skills and values. The competence of teachers in these areas is much relevant to the scientific discipline and practices (Department of Higher Education and Training, 2011, p. 49). The study document does not exclusively refer to SPS; however, SPS are inherent in the methods and procedures that are aforementioned. From the foregoing arguments it is emerges that the process of classroom instruction in the present era is expected to portray precise scientific attributes; key among them is the role of the learner in the learning process. The knowledge and skills should develop the learner wholly. The biology practical process skills that were explored in the present study are vital in ensuring effective understanding of biological principles, concepts, skills and attitudes.

Achor, Adoh and Abakpa (2018) from their study found that there were significant differences in the mean acquisition of science process skills scores $(\mathrm{P}=0.00<0.05)$ of students taught Biology concepts using laboratory strategy and expository method which was in favour of laboratory strategy group. Gacheri and Ndege (2014) conducted their study on science process skills application in practical assessments in Maara district secondary schools, in TharakaNithi County in Kenya. Findings of the research showed that most of the schools in Maara district do not adequately test students in science process skills in biology practical examination. The study also found out that, majority of the students under study agreed that the biology test require one to assemble apparatus as one of the manipulative skills tested. These studies affirm that SPS have increasingly been found to be important in learning science and for technological development of any nation. This prompted the present study to investigate whether BPPSTA influences learner attitude towards biology.

\section{Methodology}

This study adopted the quasi-experimental research design using the Solomon Four Non-Equivalent Control Group Design, (Gall, Borg \& Gall, 1996). In order to identify and select all the four co-educational County level secondary schools in Gucha south sub-County, purposive sampling technique was used. Solomon Four Non-Equivalent Control Group Design dictated the selection of the four schools. Purposive sampling technique was then used to select all the form two learners in the four sampled schools. Data for this study was collected using the Biology Attitude Questionnaire for Students, (BAQS). Pilot study was conducted before the actual study in one of the County level co-educational schools. The BAQS was validated by senior education experts in the department of curriculum, instruction and media of Kisii University. Reliability of the questionnaire was determined through split-half method (Gall et al., 2007) to a sample of form two students who did not take part in the study. A coefficient of $r=0.89$ was obtained which implied that the reliability level of the BAQS was high. Both descriptive and inferential statistics were used to analyse data that was collected on a 5-point Likert scale in the BAQS. Descriptive statistics and Independent Sample t-test were used to analyse the attitudinal means of learners from the various groups aided by the Statistical Package for Social Sciences (SPSS) version 22. These means were then used to make a deduction on the attitude level of the learners in the various groups.

\section{Results and Discussion}

To reveal the perceptions, views and inherent thoughts of the learners about biology lessons and biology practical process skills, a questionnaire dubbed BAQS was administered to the learners. The questionnaire had items on the students 'attitude towards biology practical measured on a Likert scale. A 5- point Likert scale was used to measure their responses. Analysis of the learner responses in the BAQS was done quantitatively to reveal the learners' attitude (DeWinter \& Dodou, 2010). An attitude level $\geq 3.00$ was taken to imply a positive attitude. The greater the value above 3.00 the more positive the attitude was while the lesser the value below 3.00 the more negative the attitude is towards the aspect of interest. Table 1 displays the attitudinal means obtained from the responses of the learners in the four study groups. 


\begin{tabular}{|c|c|c|c|c|}
\hline Group & Pretest/ Posttest & N & Mean & SD \\
\hline Experimental group - 1(E1) & Pretest & 119 & 3.177 & 1.382 \\
\hline & Posttest & 119 & 3.636 & 1.245 \\
\hline Control group - 1(C1) & Pretest & 64 & 2.947 & 1.270 \\
\hline & Posttest & 64 & 3.003 & 1.118 \\
\hline Experimental group - 2 (E2) & Posttest & 113 & 3.567 & 0,909 \\
\hline Control group - 2 (C2) & Posttest & 105 & 2.989 & 1.025 \\
\hline
\end{tabular}

Table 1: Descriptive Statistics Analysis for the BAQS for the Four Study Groups on Their Attitude

Table 1 shows that the lowest attitudinal mean of less than 3.00 was attained from the respondents in the E1 pretest group and the C2 posttest group. These results imply that the learners' attitude was initially negative but after the intervention, there was a positive change in the learners' attitude towards biology. A comparison of the learners' attitudinal means in the E1 posttest group and C1 posttest group, shows that the E1 had a larger deviation from pretest to posttest attitudinal means of 0.459 from 3.177 to 3.636 in comparison to that of the C1 pretest group to posttest attitudinal mean of 0.056 from 2.947 to 3.003. This shows a generally higher positive rise in the experimental groups than in the control group. The E2 group recorded the highest attitudinal mean. For further analysis, the BAQS has nine question items that addressed the attitude towards practical lesson and the other nine items addressing attitude towards biology practical process skills. This output is presented separately in the two sections that follow as per the research objectives.

\subsection{Learner Attitude towards Biology Practical Lessons}

The first nine question items were specifically to get the attitude of the learners towards the biology practical lessons in biology. Biology practical is a key component in development of biology concepts, skills, values and attitudes in biology. A comparison of the attitudinal mean of learners in various groups were done. An independent samples t-test was conducted in the various sets of study group attitudinal means. To start with, a comparison was done for the pretest and posttest attitudinal means of the E1 group. Table 2 displays the output emanating from this comparative analysis.

\begin{tabular}{|c|c|c|c|c|c|c|}
\hline Group & N & Mean & SD & df & $\begin{array}{c}\text { t- } \\
\text { value }\end{array}$ & p-value \\
\hline $\begin{array}{c}\text { Experimental group - 1 Pretest } \\
\text { Experimental group - 1 Posttest }\end{array}$ & 119 & 3.191 & 1.437 & 23 & 3.678 & .007 \\
\cline { 2 - 7 } & 119 & 3.837 & 1.354 & & & \\
\hline
\end{tabular}

Table 2: An Independent Samples T-Test for BAQS for Experimental Group -1 Pretest and Posttest

Table 2 presents results that show that there was a significant difference in the learners' attitudinal mean in E1 posttest group ( $\mathrm{M}=3.191, \mathrm{SD}=1.437)$ and the learners' attitudinal mean in posttest of the same group $(\mathrm{M}=3.837, \mathrm{SD}=1.354)$ in the attitude in the BAQS; $\mathrm{t}(236)=3.678, \mathrm{p}=007$. Since the $\mathrm{p}$-value of .007 obtained was $<.05$ for these question items where the concern was the views of respondents about the biology practical lesson, therefore it implies that the attitudinal mean scores were significantly different. The interpretation from the results was that the learner attitudinal mean observed in the E1 posttest group is significantly greater than that obtained in the posttest for the respective question items by 0.646 . This implies the attitude of the learners in the E1 changed and became more positive after the learners in this group undergoing instruction via the BPPSTA. Therefore, for these nine question items the learners' attitude level towards biology practical lessons had improved to the positive direction. Ackon, (2014) posits that, when learners are engaged in classroom practical activities in groups, they tend to learn more by advancing more positive attitude towards the subject, their peers and also their teachers. In the present study the learners carried out the practical activities in small groups of about 5 to 6 students. From another study by Gultepe (2016), similar observations have been made; that majority of the teachers who took part in the study were of the view that SPS can best be acquired through the use of laboratory activities in which not only learners are involved in but also teachers. In the present study learners underwent instruction using BPPSTA which was an entirely laboratory approach. In the approach learners carried out various practical activities that emphasized on the six practical process skills under study. The activities required learner active participation and involvement. The results are therefore showing a positive rise in the learners' attitude after instruction through the BPPSTA.

A further analysis was carried out to compare the learners' attitude towards biology practical lessons in E2 and the C2. Learners in the E2 group had been taught through BPPSTA in comparison to the learners in the C2 group who had undergone instruction through the conventional methods. The attitude of the learners in these two study groups therefore had to be compared to determine whether the attitudinal difference between them was a significant. To that effect, an independent samples t-test analysis was conducted for the purpose of this attitudinal comparison. Table 4.5.7 shows the output from the analysis. 


\begin{tabular}{|c|c|c|c|c|c|c|}
\hline Group & $\mathbf{N}$ & Mean & SD & df & t-value & p-value \\
\hline $\begin{array}{c}\text { Experimental group - 2 Posttest } \\
\text { Control group - 2 Posttest }\end{array}$ & 113 & 3.888 & 1.332 & 21 & 4.050 & .004 \\
& & & & 6 & & \\
\cline { 2 - 7 } & 105 & 3.122 & 1.475 & & & \\
\hline
\end{tabular}

Table 3: An Independent Samples t-test for the BAQS for the Experimental

Group - 2 and Control Group - 2 Posttest

Table 3 presents results that show that there was a significant difference in the learner's attitudinal mean in E2 posttest group ( $\mathrm{M}=3.888, \mathrm{SD}=1.332)$ and the attitudinal mean of learners in $\mathrm{C} 2$ posttest group $(\mathrm{M}=3.122, \mathrm{SD}=1.475)$ in the attitude in the BAQS; $t(216)=4.050, p=.004$. Since the $p$-value of .004 obtained was $<.05$ it indicates that there is a significant difference between the learners' attitudinal mean for E2 and C2 posttest groups on attitude towards practical lessons. The attitude of the respondents in the E2 group who had been taught via the use of BPPSTA was more positive as compared to that of the respondents in the $\mathrm{C} 2$ group who had been taught via the conventional methods by 0.766 .

The essence of Solomon's four non-equivalent control group design is to rule out any other possible cause of the change (in case there is) in the experimental group posttest results and attribute it to the treatment that was applied alone. Therefore, a further comparison was carried out between the attitudinal responses of the learners in the $\mathrm{C} 1 \mathrm{pretest}$ group and the attitudinal responses of learners in the $\mathrm{C} 1$ posttest group. This was the group in which the learners had undergone instruction via the conventional methods. Their attitude was determined before the instruction as pretest and then also after the instruction as posttest. An independent samples t-test was conducted so as to determine whether the learners' attitudinal means in $\mathrm{C} 1$ pretest and posttest group were significantly different. Table 4 presents the output from this analysis.

\begin{tabular}{|c|c|c|c|c|c|c|}
\hline Group & $\mathbf{N}$ & Mean & SD & df & t-value & p-value \\
\hline $\begin{array}{c}\text { Control group - 1 Pretest } \\
\text { Control group - 1 Posttest }\end{array}$ & 64 & 3.506 & 1.300 & 126 & .915 & .654 \\
\cline { 2 - 7 } & 64 & 3.529 & 1.262 & & & \\
\hline
\end{tabular}

Table 4: An Independent Samples T-Test for the BAQS for the Control Group - 1 Pretest and Posttest

Table 4 presents results that show that there was no significant difference in the learner's attitudinal mean in $\mathrm{C} 1$ posttest group $(\mathrm{M}=3.506, \mathrm{SD}=1.300)$ and the attitudinal mean of learners in posttest of the same group $(\mathrm{M}=3.529$, $\mathrm{SD}=1.262)$ in the attitude in the BAQS; $\mathrm{t}(126)=.915, \mathrm{p}=654$. Since the $\mathrm{p}$-value of .654 obtained was $>.05$ it shows that the difference between the attitudinal mean of the learners in the $\mathrm{C} 1$ pretest and posttest groups were not significant. Having undergone instruction through the conventional approaches did not impact on the learners' attitude towards biology practical. This implies that the use of the conventional teaching methods did not result into any significant change in the learners' attitude towards biology practical lessons.

These results from Table 4 informs the study that the prior difference that had been witnessed in the attitudinal mean responses in the pretest and posttest of the E1 group cannot be attributed to chance but instead can specifically be attributed to the intervention that the respondents in the E1 group had been subjected to prior to the posttest BAQS administration. The researcher can therefore associate the improved positive attitude of the learners to the use of the BPPSTA. According to Susanti et al. (2018) the SPS need to be the fundamental goal that should be targeted in science instruction. They influence every output from the science learning classroom. Abungu et al. (2014) opines that the main reasons for inclusion of science in the secondary school curriculum are; to create awareness on the effect of the knowledge of science in everyday life, to promote technological and socio-economic development in society. The practical activities carried out by students in class provide the foundation of technological development and make them ready to pursue courses that are related to science at tertiary level.

\subsection{Learners' Attitude towards Biology Practical Process Skills}

The other nine question items gathered data on the learners' attitude towards biology practical process skills. The learners' responses too were captured on a 5-point Likert scale. Abungu et al. (2014) observes that science practical activities provide students with opportunities to develop and practice the application of SPS that are vital in problem solving process not only in their life but also necessary for national and societal development. SPS activities when carefully practiced in the science classroom under the guidance of the teacher, results into competence among learners in carrying out of scientific investigations that ultimately lead to acquisition of scientific knowledge. The attitudinal means of learners in the various study groups were compared so as to reveal whether the learners' attitude had changed. To ascertain if the learners' attitudinal mean attained in the pretest of the E1 group was significantly different from that of the learners in the posttest of the same group of respondents, an independent samples t-test was carried out. Table 5 displays the output from this analysis. 


\begin{tabular}{|c|c|c|c|c|c|c|}
\hline Group & $\mathbf{N}$ & Mean & SD & df & t-value & p-value \\
\hline Experimental group - 1 Pretest & 119 & 2.596 & 1.400 & 23 & 3.484 & .045 \\
Experimental group - 1 Posttest & & & & 6 & & \\
\cline { 2 - 7 } & 119 & 3.240 & 1.493 & & & \\
\hline
\end{tabular}

Table 5: An Independent Samples T-Test Analysis for the BAQS for the

Experimental Group - 1 Pretest and Posttest

Table 5 presents results that show that there was a significant difference in the learner's attitudinal mean in E1 pretest group ( $\mathrm{M}=2.596, \mathrm{SD}=1.400)$ and the attitudinal mean of learners in posttest of the same group (M=3.240, $\mathrm{SD}=1.493)$ in the attitude in the BAQS; $\mathrm{t}(236)=3.484, \mathrm{p}=.045$. Since the $\mathrm{p}$-value of .045 obtained was $<.05$ therefore it implies that there is a significant difference between the attitudinal mean of the learners in the E1 pretest group and that of the learners in the E1 posttest group. The learners' attitudinal mean in the E1 posttest had risen as compared to the pretest mean by 0.644 . Therefore, the intervention has positively affected the attitude of the learners under study. The present study therefore reports that the emphasis of biology practical process skills in the teaching process results into a positive influence on learners' attitude towards biology practical process skills. These findings are in congruence with those from several other previous studies that have been carried out. From a study by Sanja (2012) on learner's attitudes towards science and mathematics it was observed that learners under study have a preference for demonstrations, applications and practical, and hands-on experimentation. It was further observed that after learners use the aforementioned classroom approaches and activities, they expressed a more positive attitude towards science and mathematics. Ackon (2010) who observes that, most students from the selected schools in the Sekondi-Takoradi Metropolis in Ghana also possessed positive attitudes toward practical lessons in science. Maranan (2017) from another study however, obtained results that are in contrast with the present study findings. The study reported a lack of significant difference between the learners' attitude towards science and their academic achievement.

A further comparison was carried out between the attitudinal mean of learners in the E2 and the C2 groups. The learners in these groups were not subjected to the pretest BAQS. The aim of inclusion of these two groups in the study was to rule out any possible effect of pretest BAQS which could have influenced their responses in the posttest BAQS. The study sought to confidently associate the change in E1 attitudinal mean to the intervention alone. Therefore, it was necessary to conduct a t-test analysis to establish whether the difference in the attitudinal means of E2 and C2 were significant. Table 6 presents the output from this analysis.

\begin{tabular}{|c|c|c|c|c|c|c|}
\hline Group & $\mathbf{N}$ & Mean & SD & $\mathbf{d f}$ & t-value & p-value \\
\hline $\begin{array}{c}\text { Experimental group - 2 Posttest } \\
\text { Control group - 2 Posttest }\end{array}$ & 113 & 3.519 & 1.368 & $\begin{array}{c}21 \\
6\end{array}$ & 6.032 & .000 \\
\cline { 2 - 7 } & & & & & \\
\cline { 2 - 7 } & 105 & 2.908 & 1.355 & & & \\
\hline
\end{tabular}

Table 6: An Independent Samples T-Test Analysis For The BAQS For The Experimental Group - 2 And Control Group - 2

Table 6 presents results that show that there was a significant difference in the learner's attitudinal mean in E2 posttest group ( $\mathrm{M}=3.519, \mathrm{SD}=1.368)$ and the attitudinal mean of learners in $\mathrm{C} 2$ posttest group $(\mathrm{M}=3.240, \mathrm{SD}=1.493)$ in the attitude in the BAQS; $\mathrm{t}(236)=6.032, \mathrm{p}=.000$. Since the $\mathrm{p}$-value of .000 obtained was $<.05$ it shows that there is a significant difference between the attitudinal mean of learners in the E2 and C2 groups. Therefore, the higher attitudinal mean witnessed in the E2 group is attributed to the intervention. The intervention involved the learners in this group being taught via the BPPSTA in comparison to the learners in the C2 group who were taught through the conventional methods. The high attitudinal mean portrays a more positive attitude of learners towards biology practical process skills. In order to rule out any other cause for the above described improved attitude, it was worth for a comparison to be done on the attitude of the learners in the pretest and posttest for the control group - 1 in BAQS. This was to reveal if really the change in attitude observed is as a result of the BPPSTA. To establish whether the learner attitudinal mean in the C1 pretest group and post-test group were significantly different, an independent samples t-test analysis was conducted. Table 7 presents the output from this analysis.

\begin{tabular}{|c|l|l|l|l|l|l|}
\hline Group & N & Mean & SD & df & t-value & p-value \\
\hline Control group - 1 Pretest & 64 & 2.965 & 1.262 & 126 & 0.707 & .951 \\
\cline { 2 - 8 } Control group - 1 Posttest & 64 & 2.896 & 1.161 & & & \\
\hline
\end{tabular}

Table 7: An Independent Samples T-Test for the BAQS for the

Control Group - 1 Pretest and Posttest

Table 7 presents results that show that there was a significant difference in the learners' attitudinal mean in C1 pretest group ( $\mathrm{M}=2.965, \mathrm{SD}=1.262)$ and the attitudinal mean of learners in the posttest of the same group (M=2.896, $\mathrm{SD}=1.161$ ) in the attitude in the BAQS; $\mathrm{t}(126)=.707, \mathrm{p}=.951$. Since the $\mathrm{p}$-value of .951 obtained was $>.05$ it implies that there was no significant change in attitudinal mean of the learners in the $\mathrm{C} 1$ group before and after instruction. The learners in this study group had undergone instruction via the conventional methods. These results point in the direction of confirming the earlier noted positive attitude in this study in the E1 group. This further confirms that the effect of the 
intervention that was of interest in this study cannot be underscored. Therefore, BPPSTA has had a positive impact on the learner attitude towards biology practical process skills.

Overall posttest attitudinal means for learners in groups E1 and C1 as depicted in Table 1 were analyzed using Cohen's $d$ to establish the effect size of the treatment for groups that were subjected to both pretest and posttest. Cohen's d result was $d=3.636-3.003 / 1.183=0.54$. The Cohen $d$ value obtained was 0.54 which is between 0.51 and 0.8 (Cohen, 2002) which implies that the effect size is moderate. Therefore, the BPPSTA had a moderate effect on the learners' attitude towards biology. Posttest attitudinal means for learners in groups E2 and C2 were also analyzed using Cohen's d to establish the effect size of the treatment of groups that were exposed to post-test only. Cohen's $d$ result was d=3.567$2.989 / 0.938=0.6$. The Cohen $d$ value obtained was 0.6 which is between 0.51 and 0.8 (Cohen, 2002) which implies that the effect size is moderate. Therefore, the BPPSTA had a moderate effect on the learners' attitude towards biology.

Similar findings have been obtained from a study by Samikwo, (2013). The study found out that students' attitudes towards biology affects their performance. Furthermore, the students in the study with positive attitude towards biology were found to score better marks in examinations as compared to those who had been found to have a negative attitude towards biology. The positive attitude was reported to have been a motivator for the learners to work hard. This hard work was ultimately reflected in the good marks scored by these learners in the examinations that they did. Similar claims have been raised by Abungu et al. (2014) who observe that, when students are involved more in science practical activities it improves their mastery of SPS and improves their understanding and application of scientific concepts. These findings from the two studies described are in congruence with the findings of the present study. The point of convergence for both studies is that the use of appropriate classroom instructional approaches and practices is a precursor to a more positive learner attitude towards biology practical process skills.

\section{Conclusion}

The decision made is to reject the first null hypothesis and conclude that there is a significant difference in the attitude of learners taught via BPPSTA and those taught via the conventional methods. On the second hypothesis the decision is equally to reject the second null hypothesis and conclude that there is a significant difference in attitude towards biology practical process skills between learners taught via the BPPSTA and those taught via the conventional methods. In both cases the learners taught via the BPPSTA had a more positive attitude than those taught via the conventional methods. Therefore, the use of BPPSTA ultimately leads to a more positive learners' attitude towards biology lesson and BPPS.

\section{Recommendation}

The study recommends that there should be policies in place by the ministry of basic education to evaluate biology teaching in secondary schools so as to ensure that appropriate methodologies such as BPPSTA are used by biology teachers. Furthermore, in-service trainings should be organized so as to refresh and remind the biology teachers on the need to use BPPSTA during instruction. These will in turn result in to a more positive attitude towards biology among students with will better their attainment and direct them in pursuit of biology-related careers.

\section{References}

i. Abungu, E. H., Okere, M. I. O. \& Wachanga, S. (2014). The Effect of Science Process Skills Teaching Approach on Secondary School Students' Achievement in Chemistry in Nyando District, Kenya. Journal of Educational and Social Research, 4(6): 359-372

ii. Achor, E. E., Odoh, C. O. and Abakpa, V.O. (2018). Use of Investigative Laboratory Strategy in Enhancing Acquisition of Science Process Skills Among Senior Secondary Biology Students. Journal of Research in Curriculum and Teaching, 1 (1): 103 - 109. Retrieved from www.journalacademia.curr

iii. Ackon, C. E. A., (2014). Challenges Associated with Science Practical Lessons Organization in Senior High Schools in Sekondi - Takoradi. Unpublished Masters Dissertation, University of Education, Winneba, Ghana

iv. Adodo, S. O. \& Gbore, L. O. (2012). Prediction of Attitude and Interest of Science Students of Different Ability on their Academic Performance in Basic science. International Journal of Psychology and Counseling, 4(6), 6872 .

v. Agogo, P.O. (2002). The Attitudes of Students as a Factor in the Learning of Integrated Science. Teachers Education Today, Journal of the Committee of Provost of Colleges of Education in Nigeria, 2(1), 63.

vi. Akinbobola, A. O. (2008). Facilitating Nigerian Physics Students' Attitude Towards the Concept of Heat Energy. Scientia Paedagogica Experimentalis, 45, 353-366.

vii. Akinyemi, O. A. (2009). Enhancing Students' Attitude Towards Nigerian Senior Secondary School Physics Through the use of Cooperative, Competitive and Individualistic Learning Strategies. Australian Journal of Teacher education, 34(1)

viii. Alkaslassy, E., \& O'Day, T. (2002). Linking Art and Science with a Drawing Class. Bioscene, 28(2). Retrieved from www.science/ bioscene

ix. Amoah, C. A., Eshun, E. \& Appiah, E. (2018). Assessing the Observation Skills of Biology Students in Selected Senior High Schools in the Eastern Region of Ghana in the International Journal of Scientific Research and Management 6 (5): 367-372. Retrieved from www.ijsrm.in

x. Aslan, A. (2015). How do Turkish Middle School Science Course Books Present the Science Process Skills? International Journal of Environmental \& Science Education, 10(6): 829-843 
xi. Bevins, S., Bryne, E., Brodie, M. \& Price, G. (2011). English Secondary School Students' Perceptions of School Science and Science and Engineering. Science Education International, 22 (4), 255-265.

xii. Cleaves, A. (2005). The Formation of Science Choices in Secondary School. International Journal of Science Education, 27 (4), 471- 486.

xiii. Cohen, J. (2002). Statistical Power Analysis for the Behavioural Sciences. Hillsdale, NJ: Lawrence Earlbaum Associates.

xiv. Department of Higher Education and Training (2011). South African National Qualification Framework Act (67/ 2008): Policy on the Minimum Requirements for Teacher Education Qualification. Pretoria: Government Printers.

xv. Dewinter, J. \& Dodou, D. (2010). Five-Point Likert Items: T-test Versus Mann-Whitney Wilcoxon. Practical Assessment, Research and Evaluation. 15(11). Retrieved from: http:/ / paveonline.net/ getvn.asp

xvi. Eila, J., Irmeli, P. \& Eija Y. (2016). Teaching Methods in Biology Education and Sustainability Education Including Outdoor Education for Promoting Sustainability-A Literature Review in The Education Science Journal. Retrieved from www.mdpi.com/ journal/ education

xvii. Ekon, E. E. \& Eni, E. I. (2015). Gender and Acquisition of Science Process Skills Among Juniour Secondary School Students in Calabar Municipality: Implication for Implementation of Universal Basic Education Objectives. Global Journal for Educational Research.14: 93-99. Retrieved from www.globaljournalseries.com

xviii. Gacheri, G. \& Ndege, N. M. (2014). Science Process Skills Application in Practical Assessments in Maara District Secondary Schools, Kenya. International Journal of Social Sciences and Entrepreneurship, 1 (12), 102-131.

xix. Gall, M. D., Borg, W. R.\& Gall, J. P. (1996). Educational Research: An Introduction. New York: Longman.

xx. Gall, M. D., Borg, W. R. \& Gall, J. P. (2007). Educational Research: An Introduction. (New Edition). New York: Longman.

xxi. Gultepe, N. (2016). High School Science Teachers' Views on Science Process Skills. International Journal of Environmental \& Science Education, 2016, 11(5), 779-800. Retrieved on 15th March 2020 from doi: $10.12973 /$ ijese.2016.348a

xxii. Hussein, I. (2015). Attitudes of Secondary School Students Towards Biology as a School Subject in Birnin Kebbi Metropolis, Nigeria. International Journal of Research and Review. Retrieved from: www.gkpublication.in

xxiii. KIE, (2006). Ministry of Education: Teacher's Handbook for Secondary Biology. Nairobi: Kenya Institute of Education

xxiv. Maranan, V. M. (2017). Basic Process Skills and Attitude Toward Science: Inputs to an Enhanced Students' Cognitive Performance. Unpublished Masters Thesis, Laguna State Polytechnic University, Sanpablo City Campus

xxv. Mei, G. T. Y., Kaling, C., Xinyi, C. S., Sing, J. S. K. \& Khoon, K. N. S. (2007). Promoting Science Process Skills and the Relevance of Science Through Science Alive! Programme. Proceedings of the Redesigning Pedagogy: Culture, Knowledge and Understanding Conference, Singapore, May 2007

xxvi. Molefe, L. \& Michele, S. (2014). Rhetoric and Reality: Science Teacher Educators' Views and Practice Regarding Science Process Skills, African Journal of Research in Mathematics Science and Technology Education, 18(3): 219- 230. Retrieved from: http:/ / dx.doi.org/ 10.1080/ 10288457.2014.942961

xxvii. Ngakhala, J. N., Toili, W. W \& Tsingalia, H. (2017). Participation Skills in Biology Practical per Class Level in Lugari, Kakamega County, Kenya in International Journal of Innovative Research and Development 6(6): 245249.Retrieved from: www.jiirid.com

xxviii. Ngesu, M. L., Gunga, S., Wachira, L. \& Kaluku, E. N. (2014). Some Determinants of Students Performance in KCSE: A Case of Central Division of Machakos District. International Journal of Innovative Research and Studies,3(1): 174-186

xxix. Ogutu, A. O., Yungungu, A. M., Osman, A. \& Ogolla, B. O. (2015). The Relationship Between Students Attitude Towards Biology and Performance in Kenya Certificate of Secondary Education Biology in Selected Secondary Schools in Nyakach, Kenya. Research Journal of Educational Studies and Review.1(5): 111-117. Retrieved from: http:/ / pearlresearchjournals.org/ journals/ rjesr/ index.html

xxx. Ona, E. E. (2007). Effect of Integrating Theory with Practicals on Students' Achievement in Biology. Unpublished M.Ed. Thesis, University of Nigeria, Nsukka. Retrieved from: www.university-of-nigeria/ Scienceeducation/ Ona

xxxi. Onamu, K. N. (2011). The Impact of ASEI Movement on Students' Achievement in Secondary School Biology in Nakuru County, Kenya. Unpublished M.Ed. Thesis, Kenyatta University.

xxxii. Padilla, M. (1990). The Science Process Skills. Paper 9004 in the Series, Research Matters to the Science Teacher, published by the National Association for Research in Science Teaching (NARST). Retrieved from https:/ / www.narst.org/ publications/ research/ skill.cfm

xxxiii. Prokop, P., Tuncer, G. \& Chuda, J. (2007). Slovakian Students' Attitudes Towards Biology. Eurasia Journal of Mathematics, Science \& Technology Education, 3(4):287-295

xxxiv. Rambuda, A. M. \& Fraser, W. J. (2004). Perceptions of Teachers of the Application of Science Process Skills in Teaching Geography in Secondary Schools in the Free State Province. South African Journal of Education, 24, 1017.

xxxv. Reid, N. \&Skryabina, E. (2002). Gender and Physics, 2002, International Journal of Science Education, 25(4), 509-536 
xxxvi. Sadhana (2017). Effect of Activity Based Method on Science Process Skills, Academic Achievement and Attitude of Secondary Level Students. Unpublished Ph.D. Revised Synopsis. Dayalbagh Educational Institute, Deemed University, Agra. Retrieved from: www.file.// c./ users/ hp/ downloads/ synopsis.pdf

xxxvii. Samikwo, D. (2013). Factors Which Influence Academic Performance in Biology in Kenya: A Perspective for Global Competitiveness. International Journal of Current Research. 5(12): 4296-4300. Retrieved from http:/ / www.journalcra.com

xxxviii. Sanja, R. (2012). Developing Positive Attitude towards Science and Mathematics through Motivational Classroom Experiences. Science Education International. 23(1): 6-19. Retrieved from https:/ / eric.ed.gov/ id=EJ975543

xxxix. Sharpe, M. R. (2012). Secondary School Students' Attitudes to Practical Work in School Science. Unpublished Ph.D. Thesis, University of York, England. Retrieved from https// :www.eprints.lincoln.ac.uk/ 1/ sharpe-phdThesis-2012.pdf

xl. SMASSE, (2007). Evaluation - Strengthening of Mathematics and Science in Secondary Education (SMASSE). Retrieved from http:/ / www.jaica.go.jp/ English/ evaluation

xli. Steiner, M., McNair, S. \& Butcher, J. (2001). Teaching Science Process Skills in Science and Children, 38 (4): 1822. Retrieved from: www.longwood.edu

xlii. Susanti, R, Anwar, Y. \&Ermayanti E. (2018). Profile of Science Process Skills ofPre-service Biology Teacher in General Biology Course. In the International Conference on Science Education (ICoSEd) IOP Publishing IOP Conf. Series: Journal of Physics: Conf. Series 1006 (2018) 012003 doi :10.1088/ 1742-6596/ 1006/ 1/ 012003

xliii. Suzuki, A. (2007). Attitude of Japanese Students in Relation to School Biology. Master's Thesis, University of Glasgow, Scotland. 